there has been much more awareness of the preoperative and postoperative problems and, as a result, better management. It is unreasonable to look at what happened many years ago and extrapolate to this today. What we should be doing is looking at what can be achieved and not at what has been achieved. A more realistic figure for hospital mortality from a centre dealing with more than just the occasional case would be about $10 \%$.

One of the difficulties in treating carcinoma of the cesophagus is the small number of patients. Most surgeons are unlikely to see many patients and therefore cannot become familiar with the problems that can arise in the postoperative period. One solution is to concentrate the cases in specialised centres. In the past many patients have been treated on an occasional basis as an interesting surgical challenge. This can only lead to poor results. There are many unsolved problems in the management of carcinoma of the œsophagus. These will not be solved overnight. Progress can be made if patients are treated in specialised centres by surgeons specially interested in the problem, with a supporting team of oncologists, physicians, and radiotherapists.

Wessex Cardiac and Thoracic Centre,

Southampton Western Hospital,

Southampton SO9 4WQ

R. E. LEA

SIR,-We read with interest your editorial. We also have found it difficult to reach a conclusion about the best curative therapeutic approach to squamous cell carcinoma of the œsophagus; perhaps, as you pointed out, we may have to abandon the concept of cure and attempt to restore swallowing as quickly and safely as possible. However, there are two dark areas in the literature as regards this disease which you did not mention. Firstly, the widespread metastatic nature of this disease. From necropsy findings ${ }^{1}$ and clinical experience ${ }^{2}$ it is estimated that metastases are present in more than half the patients at presentation. Secondly, amongst the hundreds of screened cytotoxic drugs none has been seriously tested against this disease. However, a few have shown some effect. For example, methotrexate, ${ }^{3}$ bleomycin, 5 -fluorouracil, and vincristine have all been used with limited success. In a pilot study we treated five patients with localised disease using methotrexate $50 \mathrm{mg}$, bleomycin $30 \mathrm{mg}$, 5-fluorouracil $500 \mathrm{mg}$ and vincristine $1 \mathrm{mg}$. The courses were repeated three to four times weekly, blood count permitting and starting two weeks after the end of the primary treatment (table).

1. Dormanns E. Das oesophaguscarcinoma: Ergebniss der unter mitarbeit von 39 pathologischen institunen Deutschlands durch gefuhrten erhebung uber das oesophaguscarcinom-(1925-1933). Z Krebsforsch 1939; 49: 86-108.

2. Ellis FH, Salzman FA. Carcinoma of the oesophagus. Postgrad Med 1977; 61: 167-74.

3. Shaw HJ. Value of cytotoxic infusion in dyspnca and dysphagia due to cancer. Lancet 1973; ii: $5 n-51$.

FAILURE OF CHEMOTHERAPY AFTER PRIMARY TREATMENT IN FIVE CASES OF OESOPHAGEAL CANCER

\begin{tabular}{|c|c|c|c|c|}
\hline No. & $\begin{array}{l}\text { Age, } \\
\text { sex }\end{array}$ & Site & $\begin{array}{c}\text { Primary } \\
\text { treatment } \\
\text { (no. of courses) }\end{array}$ & Outcome \\
\hline 1 & $70, M$ & Mid-1/3 & RT (5) & $\begin{array}{l}\text { Progressive dysphagia. Active } \\
\text { disease after 5th course. } \\
\text { Awaiting asophagectomy. } \\
\text { Alive with disease } 8 \text { mo. }\end{array}$ \\
\hline 2 & $64, F$ & Mid-1/3 & RT (4) & $\begin{array}{l}\text { Lung secondaries after } 3 \text { rd } \\
\text { course. Died. }\end{array}$ \\
\hline 3 & $60, F$ & Mid-1/3 & RT (4) & $\begin{array}{l}\text { Progressive dysphagia. Died } \\
\text { bronchopneumonia } 6 \text { mo. }\end{array}$ \\
\hline 4 & $69, M$ & Upper-1/3 & RT (3) & $\begin{array}{l}\text { Progressive local disease. Liver } \\
\text { secondaries. Died } 6 \mathrm{mo} .\end{array}$ \\
\hline 5 & $69, \mathrm{~F}$ & Lower-1/3 & $\mathrm{RT}(2)^{\star}$ & $\begin{array}{l}\text { Bone secondaries after } 2 \text { nd } \\
\text { course. Died } 7 \text { mo. }\end{array}$ \\
\hline
\end{tabular}

* Radiotherapy for residual disease following csophagectomy.
This combination was well tolerated by all patients. We noted no serious hæmatological, pulmonary, or renal complications but it was ineffective in stopping the development of metastatic disease. None of the patients completed the planned six courses, and in three of them metastatic disease developed while they were on treatment.

The incidence of œophageal cancer is increasing in both sexes. In 1975 this disease claimed the lives of 3370 patients in England and Wales. Most were elderly. However, $30 \%$ were 60 years of age or younger. The number of patients we treated is small and it is wrong to draw a conclusion from such a survey. We feel that aggressive surgery and/or radiotherapy should be carried out for patients with localised disease and chemotherapy in the young and relatively fit patient. In patients with poor general condition or metastatic disease swallowing should be restored as safely and quickly as possible.

Regional Centre of Radiotherapy and Oncology, St Luke's Hospital, Guildford GU1 3NT

A. Y. Rostom ANNE FOLKES W. F. WHITE

\title{
EFFECT OF SMOKING DURING PREGNANCY ON APGAR AND BAYIEY SCORES
}

SIR,-The effects of maternal smoking during pregnancy on the size and the developmental status of the neonate and the relation between maternal cigarette usage and growth through to the seventh year ${ }^{1}$ are well known; however, there is less information on the effect of maternal smoking on the commonly used tests such as the Apgar and Bayley scores.

We have explored the relation between maternal cigarette usage (arranged by half-pack units) and the percentage of infants with low Bayley scores at 8 months ${ }^{2}$ among 22159 Blacks and 21329 Whites analysed separately. We used cut-off values of 74 for the Bayley mental and 26 for the Bayley motor scores. For the Apgar tests done $1 \mathrm{~min}$ and $5 \mathrm{~min}$ after birth ${ }^{3}$ we used the conventional cut-off value of $7^{4,5}$ as well as lower values $(2,3$, and 5) described here as "very low" or "depressed" Apgar scores.

As shown in table I, the frequency of low Bayley scores increased by half in the progeny of women who smoked two packs a day or more during pregnancy. This was true for Blacks and for Whites and for both motor and mental items. The relation between maternal smoking (in half-pack units) and \% of low Bayley scores was roughly linear, simulating a dose-response relationship. ${ }^{6}$ While a similar relation was not found for the conventional Apgar cut-off value of 7 , it was consistently repeated at scores of 5 and below. Apgar scores of 2 (severely depressed) increased dramatically in percentage with increasing maternal cigarette usage, more than doubling at high levels of cigarette smoking during pregnancy (figure). Apgar cut-off values of 3 and 5 showed similar patterns.

Since maternal smoking during pregnancy increases the risk of prematurity ${ }^{7}$ and since prematurity affects the Bayley scores the analyses were repeated, after the exclusion of infants of less than 38 weeks' gestation length. The relation between maternal smoking and percent of low Bayley and Apgar scores remained much the same (table II). Even for Black women (who tended to smoke less and were characterised by a larger proportion of below-term neonates) smoking levels were systematically related to the percent of low Apgar and low Bayley scores. The proportion of low Bayley test

1. Garn SM, Keating MT. Effect of various prenatal determinants on size and growth through seven years. Ecol Food Nutr 1980; 9: 109-12.

2. Bayley N. Bayley scales of infant development. The Psychological Corporation, 1969

3. Apgar V. A proposal for a new method of evaluation of the newborn infant. Curr Res Anesth Analg 1953; 32: 260.

4. Drage JS, Berendes H. Apgar scores and outcome of newborn. Pediat Clin North Am 1966; 13: 635-43.

5. Niswander KR, Friedman EA, Hoover DB, et al. Fetal morbidity following potentially anoxigenic conditions. Am 7 Obstet Gynecol 1966; 95: 838-45.

6. Garn SM, Shaw HA, McCabe KD. Dose-response effect of maternal smoking. Pediatrics 1978; 62: 861-62.

7. Garn SM, Shaw HA, McCabe KD. Relative effect of smokng and other variables on size of newborn. Lancet 1977; ii: 667 . 
TABLE I-RELATION BETWEEN MATERNAL CIGARETTE USAGE AND FREQUENCY $(\%)$ OF LOW INFANT TEST SCORES

\begin{tabular}{l|r|r|r|r}
\hline \multirow{2}{*}{ Test } & \multicolumn{4}{|c}{ Maternal cigarette usage/day } \\
\cline { 2 - 5 } & \multicolumn{1}{|c|}{0} & $1-20$ & $21-40$ & $41-60$ \\
\hline Bayley motor (<26) White & $10 \cdot 1$ & $10 \cdot 2$ & $13 \cdot 8$ & $15 \cdot 8$ \\
Bayley motor (<26) Black & $9 \cdot 7$ & $10 \cdot 2$ & $11 \cdot 8$ & $11 \cdot 8^{\star}$ \\
Bayley mental (<74) White & $10 \cdot 2$ & $10 \cdot 5$ & $12 \cdot 5$ & $15 \cdot 8$ \\
Bayley mental (<74) Black & $15 \cdot 2$ & $15 \cdot 2$ & $17 \cdot 9$ & $23 \cdot 5 \star$ \\
Apgar 1 min (<2) White & $3 \cdot 4$ & $4 \cdot 0$ & $3 \cdot 8$ & $8 \cdot 3$ \\
Apgar 1 min (<2) Black & $3 \cdot 6$ & $3 \cdot 9$ & $5 \cdot 9$ & $22 \cdot 7$ \\
Apgar 5 min (<2) White & $0 \cdot 8$ & $1 \cdot 0$ & $1 \cdot 2$ & $3 \cdot 3$ \\
Apgar 5 min (<2) Black & $1 \cdot 2$ & $1 \cdot 2$ & $2 \cdot 9$ & $8 \cdot 3$ \\
\hline
\end{tabular}

${ }^{\star} \mathrm{n}<20$.

TABLE II-RELATION BETWEEN MATERNAL CIGARETTE USAGE AND FREQUENCY (\%) OF LOW TEST SCORES IN TERM INFANTS*

\begin{tabular}{|c|c|c|c|c|}
\hline \multirow[b]{2}{*}{ Test } & \multicolumn{4}{|c|}{ Maternal cigarette usage/day } \\
\hline & 0 & $1-20$ & $21-40$ & $41-60$ \\
\hline Bayley motor $(\leqslant 26)$ White & $8 \cdot 5$ & $9 \cdot 6$ & $11 \cdot 4$ & $11 \cdot 5$ \\
\hline Bayley motor $(\leqslant 26)$ Black & $7 \cdot 0$ & $6 \cdot 9$ & $9 \cdot 3$ & $11 \cdot 1+$ \\
\hline Apgar $1 \min (\leqslant 2)$ White & $2 \cdot 8$ & $3 \cdot 2$ & $2 \cdot 9$ & $6 \cdot 7$ \\
\hline Apgar 1 min $(\leqslant 2)$ Black & $2 \cdot 9$ & $2 \cdot 9$ & $4 \cdot 7$ & 30 \\
\hline
\end{tabular}

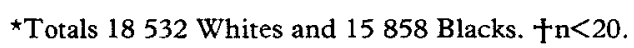

scores increased by half with heavy cigarette usage. The proportion of very low or depressed Apgar scores more than doubled at the two pack level of smoking during pregnancy.

This simple relation between the extent of maternal smoking during pregnancy and the percentage of neonates and infants deemed "low" or "depressed" on Apgar scores at birth and "low" on Bayley score at 8 months extends our knowledge of the effects of smoking in pregnancy. The results also bear on the Apgar and Bayley tests themselves. Both are clearly affected by maternal smoking, and it is reasonable to suggest some upward revision of the

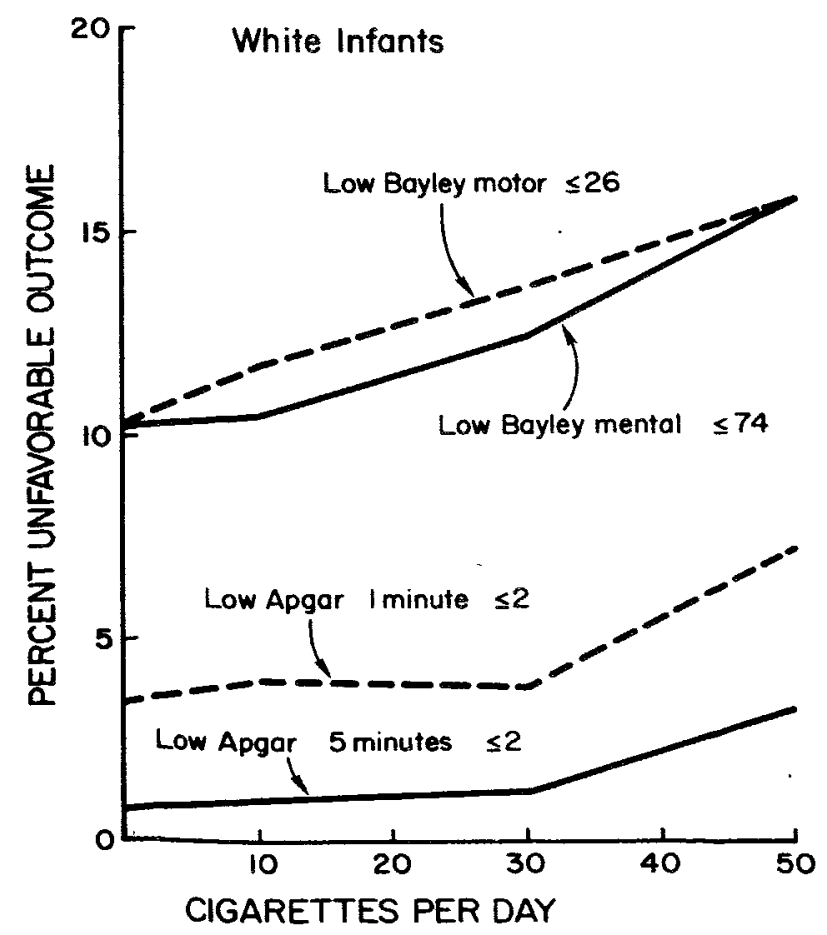

Relation between maternal smoking during pregnancy and percent of low Bayley and very low Apgar scores in White infants. standards for the progeny of non-smoking mothers. Furthermore low Apgar scores (5 and less) reflect maternal smoking more effectively than does the conventional cut-off score of 7 .

The data were drawn from the Collaborative Perinatal Project of the National Institute of Neurological and Communicative Disorders and Stroke. The study was supported by funds from contract N01-NS-5-2308.

Center for Human Growth

and Development;

and Division of Pedtatric Neurology

University of Michigan,

Ann Arbor, Michigan 48109, U.S.A.
S. M. GARN

A. S. Petzold

S. A. RIDEl.t.A

M. JOHNSTON

\section{PREMATURE RUPTURE OF MEMBRANES AND PERINATAL ASPHYXIA}

SIR,-Naeye and Peters ${ }^{1}$ noted that low Apgar scores were significantly more frequent in the presence of premature rupture of the membranes. To emphasise this relationship we analysed the perinatal records of 113 infants under 36 weeks gestational age. Asphyxia neonatorum occurred in 11 infants $(9 \cdot 7 \%)$. Among 94 infants born without premature membrane rupture, $7(7 \cdot 4 \%)$ were asphyxiated. 19 infants were born after premature rupture of the membranes with 4 infants $(21 \%)$ asphyxiated. Gestational age did not affect this relationship (table).

FREQUENCY OF AMNIONITIS AND NEONATAL ASPHYXIA

\begin{tabular}{c|c|c|c|c|c}
$\begin{array}{c}\text { Gestational age } \\
\text { (wk) }\end{array}$ & $\begin{array}{c}\text { Birthweight }(\mathrm{g}) \\
\text { (mean) }\end{array}$ & $\begin{array}{c}\text { Premature } \\
\text { rupture of } \\
\text { membranes }\end{array}$ & No. & Amnionitis & Asphyxia \\
\hline$<32$ & 1220 & No & 49 & 3 & 5 \\
& 1266 & Yes & 9 & 2 & 2 \\
2075 & No & 45 & 1 & 2 \\
1935 & Yes & 10 & 1 & 2 \\
\hline
\end{tabular}

Premature rupture of the membranes is often described in association with amniotic fluid infections and with the risk of respiratory distress syndrome. ${ }^{2}$ This complication has not been frequently related to perinatal asphyxia. Bada and co-workers ${ }^{2}$ described a fourfold increase in the incidence of asphyxia among infants born after prematurely ruptured membranes compared with controls. In a large retrospective review focusing on other aspects of the complication, Jones et al. ${ }^{3}$ noted a doubling in the occurrence of asphyxia in these infants.

Bada suggested that the resulting decrease in amniotic fluid volume harms fatal breathing movements which then further compromise the first breath. A more likely explanation may be that the increased incidence of amnionitis that occurs with prematurely ruptured membranes also plays an important role in the outcome. As noted by Naeye and Peters amniotic fluid infection may be a cause of premature membrane rupture as well as consequence. Infection may be the reason for the low Apgar scores, a conclusion supported by our own data; amnionitis occurred in $15.8 \%$ of infants with prematurely ruptured membranes compared with $4 \cdot 2 \%$ of the controls.

Department of Pediatrics

College of Medicine and Dent sstry

of New Jersey,

Rutgers Medical School,

Piscataway, New Jersey 08854, U S.A

THOMAS HEgYI I. Mark HiatT

1. Naeve RL, Peters EC. Causes and consequences of premature rupture of fetal membranes Lancet 1980; 192.

2 Bada HS, Aloıpan LC, Andrews BF. Premarure rupture of membranes and its effect on the newborn. Pediat Clin N Am 1977; 24: 491

3. Jones MD, Burd LI, Bowes WA, et al. Fallure of association of premature rupture of membranes with respiratory distress syndrome $N$ Engl Y Med 1979; 292: 1253 